\title{
PENGEMBANGAN QUICK CHANGE TOOLPOST PADA MESIN BUBUT CIAMIX UNTUK MENDUKUNG PEMBELAJARAN PRAKTIK PEMESINAN BUBUT
}

\author{
Achmad Arifin ${ }^{1)}$, Surono ${ }^{2)}$ \\ 1,2 Fakultas Teknik Universitas Negeri Yogyakarta \\ email: achmadarifin@uny.ac.id
}

\begin{abstract}
ABSTRAK
Tujuan penelitian ini untuk: (1) mengembangkan produk Quick Change Toolpost Sets and Holders yang dapat digunakan pada mesin bubut Ciamix SP $6230 \mathrm{~T}$, (2) mendapatkan hasil produk Quick Change Toolpost Sets and Holders yang layak digunakan dalam pembelajaran praktik pembubutan. Penelitian ini menggunakan pendekatan Research and Development dengan tahapan pengembangan yaitu: (1) studi pendahuluan, (2) produksi, (3) evaluasi produk, dan (4) diseminasi. Validasi produk dengan uji kelayakan oleh ahli pembelajaran dan praktisi pemesinan bubut, sedangkan uji coba produk oleh mahasiswa dengan metode angket. Teknik analisis data yang digunakan adalah teknik analisis statistik deskriptif. Hasil penelitian dan pengembangan ini adalah produk berupa Quick Change Toolpost Sets and Holders yang memiliki spesifikasi dan keunggulan yaitu: dapat digunakan pada mesin bubut Ciamix seri SP $6230 \mathrm{~T}$, memiliki 2 holders pahat yang terpasang pada toolpost, dan pengaturan tinggi holder pahat cukup dilakukan hanya dengan memutar baut pengatur sehingga ujung mata sayat pahat akan dengan mudah diatur setinggi senter mesin bubut. Produk ini memudahkan operator mesin bubut dalam menyetel tinggi pahat, tidak perlu menggunakan plat pengganjal dan lebih hemat waktu kerja dalam mengatur tinggi pahat. Produk ini memiliki kelayakan dengan skor sebesar 3,64 yang berarti "BAIK", sehingga dapat digunakan dengan baik secara fungsional maupun operasional, mampu menahan getaran akibat putaran mesin pada proses pembubutan, dan hasil pembubutan dengan beberapa variasi putaran maupun tebal pemakanan menunjukkan hasil yang baik.
\end{abstract}

Kata kunci: quick change toolpost, mesin bubut Ciamix, praktik pemesinan bubut

\begin{abstract}
The purposes of this study were: (1) product development of Quick Change Toolpost Sets and Holders that can be used on a lathe Ciamix SP $6230 \mathrm{~T}$, (2) getting the product Quick Change Toolpost Sets and Holders are eligible for use in the practice of turning learning. This study uses the approach of Research and Development at the development stages, namely: (1) a preliminary study, (2) production, (3) evaluation of product, and (4) dissemination. Validation of products were with due diligence by learning experts and practitioners machining lathe, while product testing by students by questionnaire. Data analysis technique used is descriptive statistical analysis techniques. The results of this research and development is the a product of the Quick Change Toolpost Sets and Holders that have specifications and advantages, namely: it can be used on a lathe Ciamix SP series $6230 \mathrm{~T}$, it has two holders chisel mounted on toolpost, and chisel holder height setting is done simply by turning the screw regulator, so that the tip of the cutting chisel will be easily set as high as center lathe. This product makes easly a lathe operator in a high set chisel, do not need to use the mounting plate and more efficient working time in high chisel set. This product has eligibility with a score of 3.64 , which means "GOOD", so it can be used with both functional and operational, able to withstand the vibration caused by engine speed at the turning process, and the result of turning with a few variations and depth feeds has shown good results.
\end{abstract}

Keywords: quick change toolpost, Ciamix turning machine, practice of turning learning 


\section{PENDAHULUAN}

Proses pemesinan bubut adalah suatu proses untuk membuat bentuk dan ukuran benda kerja dengan cara menyayat benda kerja yang berputar dengan menggunakan alat potong yang berupa pahat pada mesin perkakas bubut. Widarto (2008) menjelaskan bahwa bentuk dasar proses bubut dapat didefinisikan sebagai proses pemesinan permukaan luar benda silindris atau bubut rata dengan: (1) Benda kerja yang berputar, (2) Satu pahat bermata potong tunggal (with a single-point cutting tool), dan (3) Gerakan pahat sejajar terhadap sumbu benda kerja pada jarak tertentu sehingga akan membuang permukaan luar benda kerja.

Praktik permesinan bubut adalah bentuk proses pembelajaran produktif yang mengajarkan materi kompetensi permesinan dengan menggunakan mesin bubut kepada para mahasiswa yang ingin menguasai kompetensi tersebut dengan cara atau metode yang baku dan benar. Kompetensi permesinan bubut tersebut meliputi membubut muka, membubut rata, membubut poros bertingkat, membubut tirus, membubut alur, membubut ulir, membuat luar dan dalam, pengetahuan tentang jenis dan fungsi alat potong (pahat), parameter pembubutan dan aspek keselamatan kerja yang harus diperhatikan.
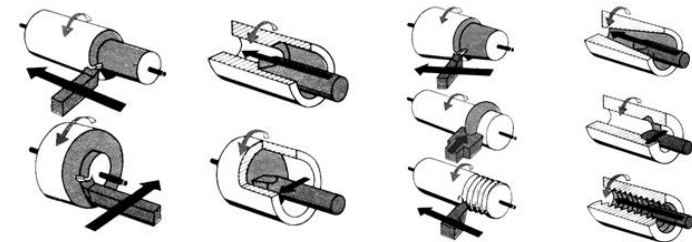

Gambar 1. Bentuk Dasar Kerja Pembubutan

Bentuk dasar benda kerja yang dapat dikerjakan dan dihasilkan dengan menggunakan mesin bubut adalah sebagai berikut: bentuk poros/lubang silindris, bentuk permukaan rata, bentuk tirus/konis luar, bentuk tirus/konis dalam, bentuk bulat/profil, bentuk ulir luar, bentuk ulir dalam dan bentuk alur dalam. Bentuk dasar benda kerja yang dimaksud tersebut adalah sebagaimana ditunjukkan secara visual pada Gambar 1.

Pemesinan Bubut merupakan salah satu mata kuliah praktik pada kurikulum 2014 yang dilaksankan di Jurusan Pendidikan Teknik Mesin Fakultas Teknik Universitas Negeri Yogyakarta dengan bobot 3 sks praktik. Nurdjito (2015) dalam Rencana Pembelajaran Semester (RPS) yang disusun menjelaskan bahwa capaian pembelajaran yang diharapkan adalah: mahasiswa memiliki pengetahuan dan terampil mengoperasikan mesin bubut untuk menghasilkan berbagai jenis produk/ komponen mesin yang memiliki ketelitian geometris sesuai standar yang ditentukan cermat, teliti dan hati-hati dalam mempersiapkan alat potong (pahat) yang akan digunakan, merancang dan melaksanakan proses pembubutan serta dalam melakukan pengukuran untuk kontrol kualitas produk (komponen) yang dihasilkan.

Observasi awal yang telah dilakukan oleh tim peneliti menemukan fakta bahwa: (1) Pemesinan Bubut merupakan mata kuliah praktik yang paling awal diberikan dengan menggunakan mesin perkakas. (2) mahasiswa peserta praktik Pemesinan Bubut, khususnya yang diampu oleh peneliti adalah hampir semua merupakan lulusan SMA yang tidak memiliki pengalaman praktik dengan menggunakan mesin bubut, dan (3) dukungan kelengkapan sarana dan peralatan/ fasilitas praktik, khususnya: mesin bubut, alat potong dan alat bantu praktik lainnya dalam kondisi yang relatif kurang baik.Salah satu jenis mesin bubut yang banyak tersedia di Workshop Fitting Jurusan Pendidikan Teknik Mesin FT UNY adalah mesin bubut Ciamix SP $6230 \mathrm{~T}$.

Kondisi bahwa sebagian besar peserta kuliah praktik Pemesinan Bubut adalah mahasiswa yang minim pengalaman bahkan banyak yang belum pernah menggunakan mesin bubut dan perlengkapannya membuat proses pembelajaran praktik mengalami sedikit hambatan. Hal lain yang juga merupakan 
hambatan dalam pembelajaran Pemesinan Bubut adalah terkait dengan kualitas peralatan dan fasilitas praktik yang kurang baik. Berikut ini adalah beberapa kendala teknis yang sering terjadi selama proses pembelajaran praktik Pemesinan Bubut, yaitu: (1) mesin bubut sering bermasalah, (2) ukuran dan jenis pahat bubut yang berbeda-beda sehingga perlu lebih dipahamkan kepada mahasiswa terkait setting pahat bubut, (3) ketersediaan pengganjal pahat yang terbatas, ketebalan pengganjal kurang bervariasi, sehingga sulit mencapai tinggi sisi sayat ujung pahat yang presisi terhadap center benda kerja, dan (4) ujung center kepala lepas banyak yang sudah tumpul, sehingga sulit untuk digunakan sebagai pedoman setting tinggi sisi sayat pahat agar setinggi center benda kerja. Beberapa kendala teknis tersebut menyebabkan mahasiswa memerlukan waktu yang lebih lama untuk melakukan persiapan proses pembubutan.

Terkait dengan pengaturan tinggi center sisi sayat pahat, maka salah satu bagian mesin bubut yang sangat berperan adalah tool post. Tool post atau sering juga disebut dengan rumah pahat yang berfungsi untuk memegang alat potong (pahat bubut atau kartel) yang dipergunakan pada proses pembubutan. Tool post terletak pada dudukan yang terdapat di bagian eretan atas. Tool post dapat digerakkan relatif terhadap benda kerja di sepanjang alas mesin baik dalam arah membujur maupun melintang mengikuti pergerakan eretan yang ada. Selain itu tool post juga dapat digerakkan berputar secara rotasi terhadap poros sumbunya. Kemampuan perputaran tool post tersebut berfungsi untuk mengatur sudut sisi sayat pahat terhadap benda kerja agar dapat menghasilkan pembubutan yang optimal.

Alat potong pembubutan yang dapat dipasang pada tool post mesin bubut Ciamix adalah pahat bubut dengan berbagai jenisnya dan kartel. Pemasangan alat potong baik pahat bubut maupun kartel pada tool post mesin bubut Ciamix adalah dengan sebagai berikut:
Siapkan pahat bubut dan plat pengganjal, (2) Pastikan tool post dalam kondisi bersih dari bram dan kotoran lainnya, (3) Pasang plat pengganjal secukupnya pada tool post, (4) Letakkan pahat bubut di atas plat pengganjal yang sudah dipasang sebelumnya, (5) Kencangkan baut pengikat pahat. Untuk alasan keselamatan, maka minimal harus ada dua baut yang mengikat pahat tersebut, (6) Cek dan pastikan tinggi ujung mata sayat pahat setinggi center benda kerja, (7) Apabila tinggi mata sayat pahat tidak setinggi center maka, kendorkan baut pengikat dan atur kembali (tambah atau kurangi) plat pengganjal yang ada, (8) Kencangkan kembali baut pengikat pahat.

Kelemahan pemasangan alat potong pada tool post standar bawaan mesin bubut Ciamix tersebut adalah pada pengaturan untuk memperoleh tinggi center pahat yang mengandalkan penggunaan plat pengganjal. Pengaturan tinggi center pahat memerlukan waktu yang relatif lama karena harus bongkar pasang plat pengganjal sedemikian rupa agar memperoleh tinggi mata sayat pahat setinggi center. Selain itu hasil ketinggian center pahatnya sulit untuk memperoleh tingkat presisi karena sangat tergantung ketersediaan variasi tebal plat pengganjal.

Sebagai upaya untuk dapat mengatasi kendala teknis tersebut, khususnya yang terkait dengan proses setting pahat bubut, maka perlu dikembangkan suatu alat bantu berupa quick change tool post sets and holders. Ketersediaan alat bantu tersebut diharapkan dapat mengurangi lama waktu yang diperlukan untuk melakukan setting pahat bubut, sehingga proses praktik akan lebih efektif dan efisien. Quick change tool post sets and holders sebetulnya sudah tersedia di pasaran, namun dalam ukuran dan kondisi yang tidak sesuai dengan mesin bubut yang dimiliki di Workshop Fitting. Penelitian ini lebih fokus pada pengembangan quick change toolpost sets and holders yang dapat digunakan pada mesin bubut jenis Ciamix SP $6230 \mathrm{~T}$.

Quick change toolpost sets and holder didesain dan dikembangkan untuk 
mengatasi kelemahan yang ada tersebut. Pemasangan dan pengaturan tinggi pahat agar setinggi center benda kerja akan lebih praktis, mudah, lebih cepat, dan lebih presisi.

Penelitian dan pengembangan (Research and Development) adalah suatu proses atau langkah-langkah untuk mengembangkan suatu produk baru atau menyempurnakan produk yang telah ada, yang dapat dipertanggungjawabkan. Sebagaimana dijelaskan Nana Syaodih Sukmadinata (2009: 164) produk yang dikembangkan tidak selalu berbentuk benda atau perangkat keras (hardware), tetapi dapat juga perangkat lunak (sofware), ataupun model-model pendidikan, pembelajaran, pelatihan, bimbingan, evaluasi, manajemen, dll. Pendapat lain yang dikemukakan oleh Gall, Gall, \& Borg (2003: 569) menyebutkan bahwa $R$ \& $D$ dalam dunia pendidikan pengembangannya didasarkan pada model dari dunia industri dimana penemuan dari penelitian digunakan untuk mendesain produk dan prosedur baru, yang secara sistematis teruji lapangan, dievaluasi, dan disempurnakan sampai memenuhi kriteria tertentu dari segi efektivitas, kualitas, atau serupa dengan standar.

Thiagarajan (1974) mengemukakan bahwa langkah-langkah penelitian dan pengembangan terdiri dari Define, Design, Development dan Dissemination atau disingkat 4D, seperti yang ditunjukkan pada Gambar 2.

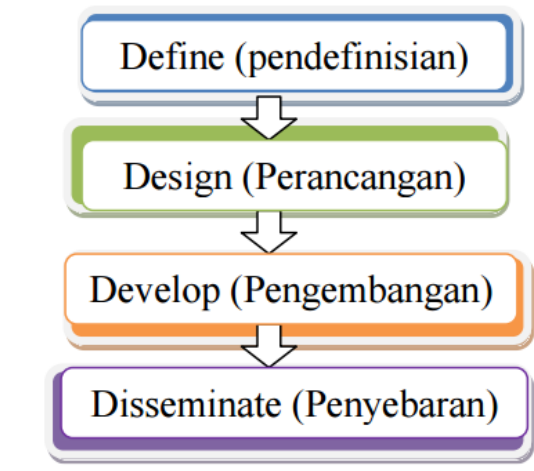

Gambar 2. Langkah Penelitian dan Pengembangan Menurut Thiagarajan
Gambar 2 di atas diberikan penjelasan oleh Sugiyono (2015: 38) sebagai berikut: Define (pedefinisian), berisi kegiatan untuk menetapkan produk apa yang akan dikembangkan, beserta spesifikasinya. Tahap ini merupakan kegiatan analisis kebutuhan yang dilakukan melalui penelitian dan studi literatur. Design (perancangan), berisi kegiatan untuk membuat rancangan terhadap produk yang telah ditetapkan. Development (pengembangan) berisi kegiatan membuat rancangan menjadi produk dan menguji validitas produk secara berulang-ulang sampai memperoleh produk sesuai dengan spesifikasi yang ditetapkan. Dissemination (diseminasi) berisi kegiatan menyebarluaskan produk yang telah teruji untuk dimanfaatkan orang lain.

Pada kasus penelitian dan pengembangan produk quick change tool post sets and holders harus memperhatikan unsur pengembangan teknis suatu produk yang spesifik. Pengembangan teknis yang tepat atas suatu desain produk merupakan salah satu syarat utama keberhasilan sebuah produk dalam memenuhi kebutuhan pengguna. Untuk mencapai hasil yang diharapkan, diperlukan beberapa langkah konstruktif yang harus dilakukan (G. Niemann, 1999:1) yaitu: (a) Produksi perdana, memenuhi target yang telah ditentukan. (b) Pengembangan lanjut, eliminasi hambatan, kesempurnaan, kesederhanaan, dan penurunan harga dari hasil desain. (c) Penyesuaian hasil desain untuk penerapan di bidang khusus dan pengembangan produksi khusus. (d) Spesifikasi khusus, menentukan ukuran tertentu, bentuk dan daya tahan khusus, jika hal ini belum dilakukan dalam langkah terdahulu. (e) Memproduksi dengan cara lain atau bahan lain. (f) Hasil desain yang lebih bermutu.

Penelitian pengembangan terkait modifikasi mesin bubut yang dilakukan oleh Aep Surahto (2008) perbaikan dilakukan secara menyeluruh dalam setiap proses, mulai dari desain manufaktur hingga diperoleh produk jadi. Hasil dari 
penelitian ini adalah bahwa produk modifikasi mesin layak digunakan di laboratorium atau di pusat reparasi mesin diesel karena sanggup bekerja di putaran 2000 rpm dengan harga terjangkau. Penelitian lainnya oleh Ignatius Aris Hendaryanto dan Andhi Akhmad Ismail (2014) tentang retrofit mesin bubut. Dalam penelitian ini dilakukan metode retrofit terhadap mesin bubut manual menjadi mesin bubut CNC dengan menambahkan sistem kontrol terhadap gerakan sumbu $X$ dan sumbu $Z$ mesin. Hasil dari penelitian ini adalah mesin bubut CNC yang mampu melakukan gerakan pemakanan interpolasi linear dan interpolasi sirkuler dengan ketelitian gerakan sumbu $X$ sebesar $0,04 \mathrm{~mm}$ dan sumbu $Z$ sebesar $0,03 \mathrm{~mm}$. Metode dan tahapan yang dipakai dalam modifikasi mesin bubut maupun retrofit tersebut secara umum dapat digunakan dan diadaptasi dalam proses penelitian pengembangan produk quick change tool post sets and holders.

\section{METODE}

Penelitian menggunakan pendekatan penelitian dan pengembangan atau Research and Development (R\&D). Penelitian ini lebih berfokus pada pengembangan dan penyempurnaan jenis produk yang telah ada sebelumnya, khususnya pada bentuk/profil dan fungsional produk. Produk yang dikembangkan adalah berupa alat bantu praktik pemesinan bubut yaitu quick change tool post sets and holders. Model pengembangan menerapkan model prosedural hasil adaptasi dari Borg \& Gall (1983) yang telah dimodifikasi oleh Nana Syaodih Sukmadinata. Secara garis besar metode yang digunakan terdiri atas empat tahap sebagaimana ditunjukkan pada Gambar 3 yaitu: (1) Studi pendahuluan, (2) produksi, (3) evaluasi produk, dan (4) diseminasi,

Studi pendahuluan dilakukan dengan cara: (a) survei lapangan yang dilakukan untuk melihat secara langsung keadaan bengkel pemesinan bubut, potensi-potensi yang dimiliki, sekaligus hambatanhambatan yang dihadapi. Selain itu juga dilakukan pengamatan terhadap proses pembelajaran pemesinan bubut serta karakteristik mahasiswa. (b) studi pustaka, yaitu melakukan kajian literatur yang relevan dengan penelitian untuk pengembangan produk quick change toolpost sets and holders. (c) identifikasi permasalahan dilakukan dengan mengumpulkan informasi mengenai permasalahan-permasalahan yang terjadi saat proses pembelajaran praktik Pemesinan Bubut berlangsung. (d) analisis kebutuhan dilakukan untuk menganalisis kebutuhan pemecahan permasalahan pembelajaran praktik Pemesinan Bubut.(e) perumusan desain produk berupa desain awal produk dituangkan dalam bentuk gambar benda kerja utuh (3D) dan gambar kerja yang disesuaikan dengan keadaan/kebutuhan mesin bubut Ciamix seri SP $6230 \mathrm{~T}$ dan karakteristik calon pengguna produk.

Proses produksi menyesuaikan dengan gambar kerja yang telah dirumuskan sebelumnya, dan dilakukan dalam empat tahap yaitu: (a) menyiapkan bahan untuk pembuatan produk quick change toolpost sets and holders. (b) pembuatan komponen sesuai gambar kerja. (c) perakitan yaitu menyatukan beberapa komponen menjadi satu kesatuan alat.(d) Tes dan perbaikan: dilakukan uji coba terhadap alat yang sudah dirakit, jika terdapat kekurangan/kesalahan segera dilakukan perbaikan, hingga diperoleh produk awal.

Kegiatan evaluasi produk sesungguhnya dilakukan secara menyeluruh dan terus menerus (ongoing evaluation) selama proses produksi. Untuk mendapatkan produk yang baik, dilakukan pula evaluasi secara khusus/spesifik yaitu: (a) Uji kelayakan oleh ahli (validasi ahli): melibatkan ahli pembelajaran pemesinan bubut dan praktisi proses pemesinan bubut, (b) Uji coba produk: proses penggunaan produk dalam pembelajaran untuk mengetahui respon mahasiswa dan kelayakan produk. Selama kegiatan evaluasi, dilakukan analisis dan perbaikan sesuai dengan temuan dan saran yang diperoleh, hingga dihasilkan produk akhir. 
Diseminasi dilakukan dengan menyampaikan produk hasil penelitian dan pengembangan kepada para pengguna dan profesional melalui forum pertemuan/seminar hasil dan/atau menuliskan dalam jurnal serta buku panduan

Sumber data diperoleh dari: (a) Validator, melibatkan ahli pembelajaran pemesinan bubut dan praktisi proses pemesinan bubut. Ahli pembelajaran pemesinan bubut dalam hal ini adalah dosen pengampu pemesinan bubut, sedangkan untuk praktisinya adalah teknisi bengkel pemesinan.

Mahasiswa, mahasiswa Jurusan Pendidikan Teknik Mesin FT UNY yang melaksanakan praktik dengan menggunakan mesin bubut Ciamix SP $6230 \mathrm{~T}$

Pengumpulan data menggunakan metode: (a) Dokumentasi, untuk mengkaji literatur yang memuat pendapat para ahli dan hasil-hasil penelitian dan pengembangan yang relevan. (b) Angket, digunakan saat uji kelayakan oleh ahli dan uji coba produk. (c) Observasi, dilakukan saat pembelajaran pemesinan bubut. Saat observasi dilakukan pula pengumpulan data untuk mengetahui kelayakan produk.

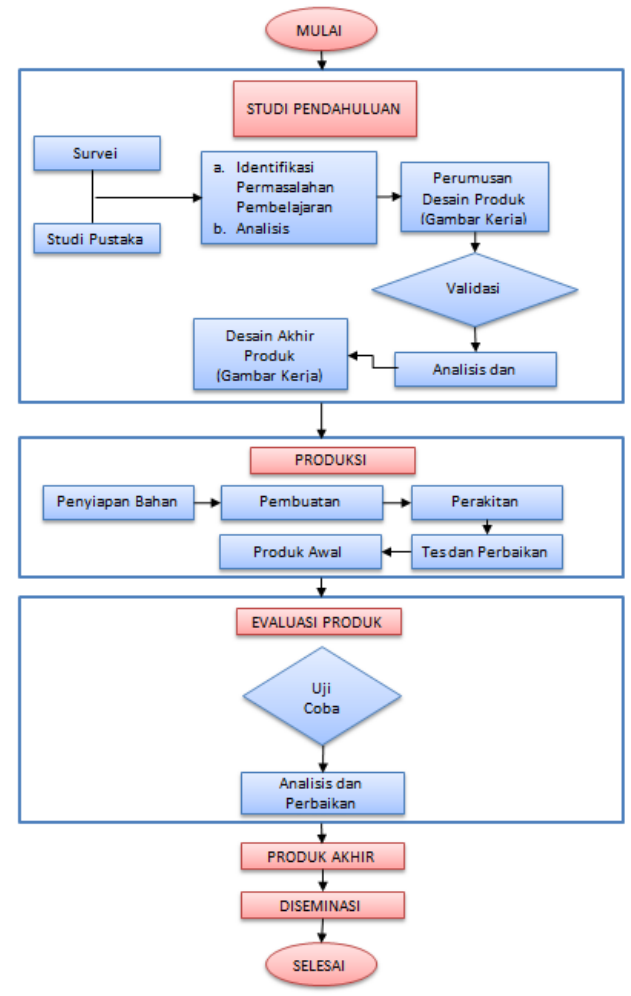

Gambar 3. Tahapan Penelitian dan Pengembangan Quick Change Tool post Sets and Holders

Teknik analisis data yang digunakan adalah statistik deskriptif, yaitu sebagai berikut: (a) Data mengenai prosedur pengembangan produk berdasarkan pendapat para ahli dan hasil-hasil penelitian pengembangan yang relevan dipilih yang sesuai dan diadaptasi untuk mengembangkan quick change tool post sets and holders. (b) Data kualitatif berdasarkan komentar atau saran dari para responden (hasil validasi ahli dan pendapat mahasiswa) disimpulkan sebagai masukan untuk memperbaiki/merevisi produk yang dikembangkan. (c) Data kuantitatif berupa hasil skoring menggunakan skala likert dianalisis agar didapat penilaian kelayakan produk yang dihasilkan.

\section{HASIL DAN PEMBAHASAN}

Sebagaimana tahapan penelitian yang ditetapkan bahwa tahapan penelitian terdiri dari studi pendahuluan, produksi, evaluasi produk dan disseminasi. Tahap pertama yang dilaksanakan adalah studi pendahuluan yang berupa observasi, analisis kebutuhan dan pembuatan desain awal produk.

Hasil observasi awal yang dilaksanakan pada pembelajaran praktik Pemesinan Bubut ditemukan bahwa terdapat kendala teknis yang menyebabkan mahasiswa memerlukan waktu yang lebih lama untuk melakukan persiapan proses pembubutan. Kendala teknis yang lebih spesifik adalah pada proses setting pahat bubut untuk memperoleh posisi tinggi sisi sayat ujung pahat setinggi center benda kerja yang lebih presisi. Atas dasar hal tersebut maka perlu dikembangkan suatu alat bantu yang dapat digunakan untuk memperoleh posisi sisi sayat setinggi center yang mudah digunakan.

Observasi lain dilakukan dengan menjelajah menggunakan mesin pencari google.com untuk menemukan produk sejenis. Hasil penelusuran menemukan 
bahwa banyak jenis alat bantu sebagaimana ditunjukkan pada Gambar 4.

Gambar 4 menunjukkan bahwa di pasaran banyak tersedia alat bantu pengatur pahat setinggi center dengan menggunakan alat quick change toolpost. Namun demikian hampir semua vendor

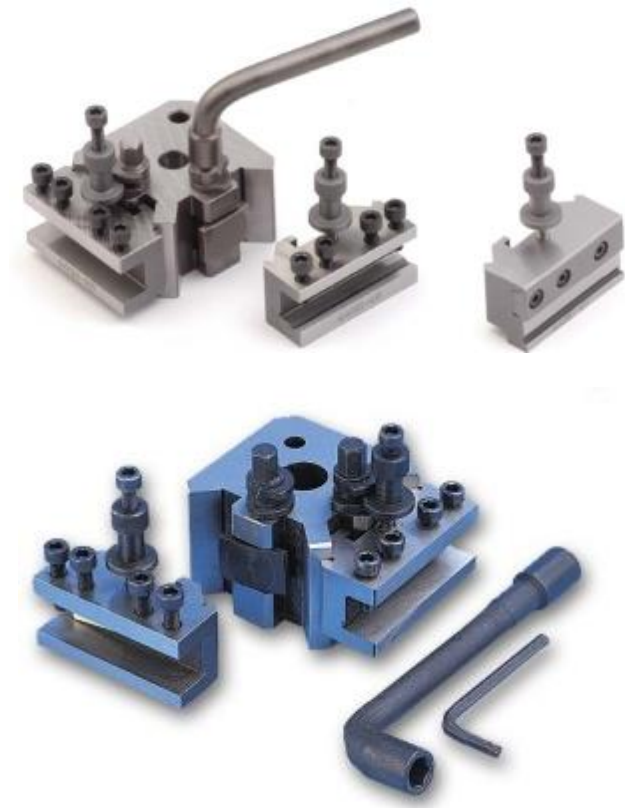

yang ditemukan dengan lokasi di luar negeri, harga yang relatif mahal dan spesifikasi ukuran yang tersedia belum tentu sesuai dengan mesin bubut yang terdapat di Workshop Fitting Jurusan Pendidikan Teknik Mesin Fakultas Teknik UNY.

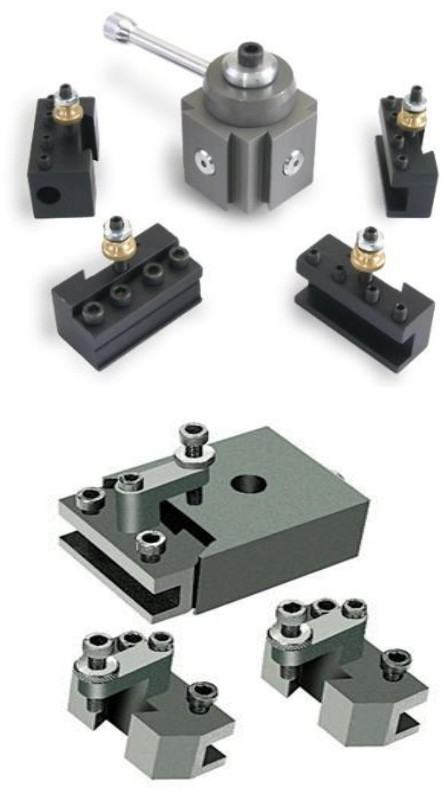

Gambar 4. Hasil Penelusuran Alat Bantu Pengatur Tinggi Pahat

Berdasarkan hasil observasi tersebut maka perlu dibuat suatu alat bantu untuk mendukung pelaksanaan praktik Pemesinan Bubut khususnya alat bantu yang dapat digunakan untuk mengatur ketinggian center pahat dengan mudah dan praktis oleh mahasiswa. Alat bantu tersebut adalah berupa quick change toolpost yang harus mampu untuk memenuhi kebutuhan sebagai berikut: (1) Mudah dioperasikan oleh mahasiswa. (2) Dapat dipasang di mesin bubut yang tersedia di bengkel (Ciamix seri SP 6230 T) dan cara pemasangan praktis pada dudukan eretan atas. (3) Dapat digunakan untuk beberapa variasi ukuran pahat bubut. (4) Dapat diatur ketinggian sisi sayat pahat dengan mudah ketika diperlukan pergantian jenis pahat. (5) Tetap stabil dan tahan terhadap getaran yang ditimbulkan karena putaran yang tinggi. (6) Tidak perlu lagi menggunakan pengganjal pahat.

Produk quick change toolpost sets and holders didesain untuk dapat digunakan pada mesin bubut Ciamix seri SP $6230 \mathrm{~T}$, memiliki 2 holders yang terpasang pada toolpost, dan pengaturan tinggi holder pahat dilakukan hanya dengan memutar baut pengatur sehingga ujung mata sayat pahat akan dengan mudah diatur setinggi senter mesin bubut, sebagaimana ditunjukkan Gambar 5.

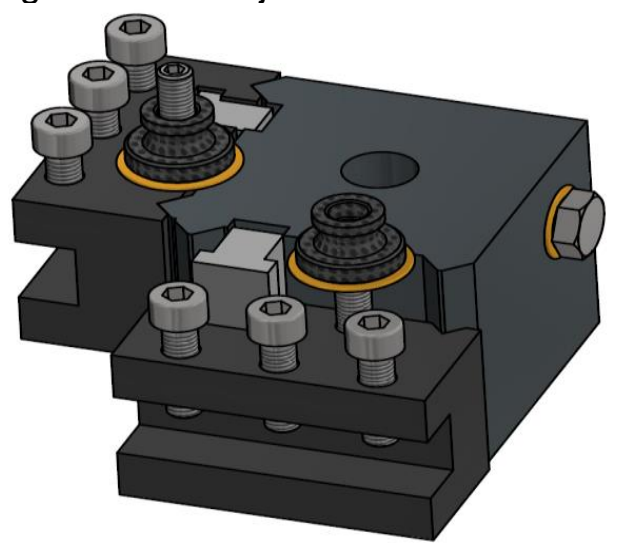

(a) Desain utuh produk 


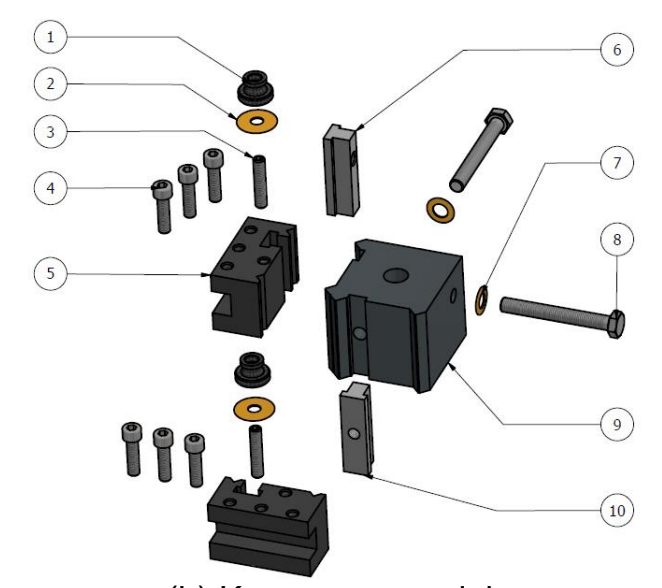

(b) Komponen produk

Gambar 5. Desain Produk Quick Change Toolpost Sets and Holders

Gambar desain awal yang sudah dibuat kemudian dilakukan validasi secara jugdment expert. Hasil penilaian oleh ahli secara kuantitatif ditunjukkan pada Tabel 1 berikut ini.

Tabel 1. Hasil Penilaian Desain Produk

\begin{tabular}{|c|c|c|c|c|}
\hline \multirow{2}{*}{ No. } & \multirow{2}{*}{$\begin{array}{c}\text { Aspek yang } \\
\text { Dinilai }\end{array}$} & \multicolumn{3}{|c|}{ Skor Penilaian } \\
\hline & & SB B CB & KB & TB \\
\hline 1. & $\begin{array}{l}\text { Konstruksi } \\
\text { (Bentuk dan } \\
\text { Geometri) }\end{array}$ & 5 (4) 3 & 2 & 1 \\
\hline 2. & Dimensi & 5 (4) 3 & 2 & 1 \\
\hline 3. & Material & 5 (4) 3 & 2 & 1 \\
\hline
\end{tabular}

Hasil penilaian oleh ahli secara kualitatif adalah bahwa produk memiliki kelebihan untuk mempercepat proses setting pahat, tidak memerlukan ganjal, dan cocok untuk beberapa ukuran pahat, sedangkan kekurangan dari desain produk yang ada adalah terdapat beberapa kesalahan kecil pada penempatan simbol di gambar kerja. Berdasarkan hasil penilaian tersebut menunjukkan bahwa desain produk yang dibuat, dilihat dari aspek bentuk dan geometri, dimensi serta material sudah masuk kategori BAIK. Penilaian dari aspek konstruksi menunjukkan bahwa tidak perlu ada perubahan atas bentuk maupun geometri desain produk yang telah dibuat. Secara keseluruhan dari hasil penilaian kuantitatif dan kualitatif desain produk Quick Change Toolpost Sets and Holders dinyatakan dapat digunakan/ dilanjutkan dengan perbaikan.

Tahap kedua adalah melakukan produksi atas desain yang sudah diperbaiki. Produk Quick Change Toolpost Sets and Holders dibuat dengan menggunakan bahan S45C. Material jenis ini paling banyak digunakan sebagai bahan pembuat komponen mesin. Hal ini dikarenakan harganya yang lebih murah dibanding material lain yang sejenis. Material S45C memiliki sifat dan karakteristik sebagai berikut: keras, tahan terhadap beban puntir, tahan aus, dan cukup ulet pada bagian inti. Pemilihan jenis bahan ini agar produk yang dihasilkan dapat diberikan perlakuan panas berupa hardening agar memperoleh kekerasan dan memiliki ketahanan aus yang lebih baik.

Komponen dengan ukuran standar yang tersedia di pasaran sehingga dapat langsung dibeli sesuai dengan kebutuhan, yaitu item komponen no 2, 3, 4, 7 dan 8 . Sedangkan item komponen lainnya yang akan dilakukan proses machining berdasarkan gambar kerja yang sudah disiapkan. Urutan pengerjaan masingmasing item komponen tersebut adalah sebagai berikut: (a) Item komponen no 9 yang merupakan komponen utama toolpost dikerjakan paling awal sesuai ukuran pada gambar kerja. Bentuk dan ukuran yang harus diperhatikan agar dicapai sesuai toleransi yang diizinkan adalah pada: lubang pada bagian tengah dengan $\varnothing 24 \mathrm{~mm}$ dan $\varnothing 17 \mathrm{~mm}$, lebar alur $13 \mathrm{~mm}$ yang terdapat pada kedua sisinya, dan bentuk dan ukuran tonjolan sebesar $5,5 \mathrm{~mm}$. Bagian ukuran tersebut akan berpasangan dengan komponen no 6, 10 dan 5. (b) Selanjutnya adalah item komponen no 6 dan 10. Komponen ini memiliki bentuk dan ukuran yang sama, perbedaannya hanya terletak pada jarak lubang ulir M10x1,5. Komponen no 6 dan 10 ini harus dipastikan dapat dipasangkan dengan baik pada bagian utama toolpost baik pada ukuran alur maupun posisi lubang ulir yang ada. (c) Berikutnya 
adalah komponen no 5 yang berjumlah 2 pcs dengan bentuk dan ukuran yang sama. Bentuk dan ukuran yang harus diperhatikan agar dicapai sesuai toleransi yang diizinkan adalah pada: alur $\mathrm{V}$ dengan sudut 900 dan kedalaman $4 \mathrm{~mm}$, dan alur $T$ yang akan dipasangkan dengan komponen no 6 atau 10. (d) Langkah selanjutnya adalah melakukan perakitan dan pengepasan masing-masing komponen yang sudah dikerjakan tersebut menjadi satu produk/alat. Perakitan dan pengepasan ini dilakukan untuk memastikan bahwa setiap komponen baik yang diproduksi sendiri maupun dibeli dapat baik secara ukuran maupun bentuk berfungsi dengan baik. (e) Kemudian dilakukan finishing sehingga diperoleh produk akhir Quick Change Toolpost Sets and Holders yang siap untuk dilakukan uji coba fungsional maupun operasional. Hasil proses produksi dari komponenkomponen tersebut ditunjukkan pada Gambar 6.

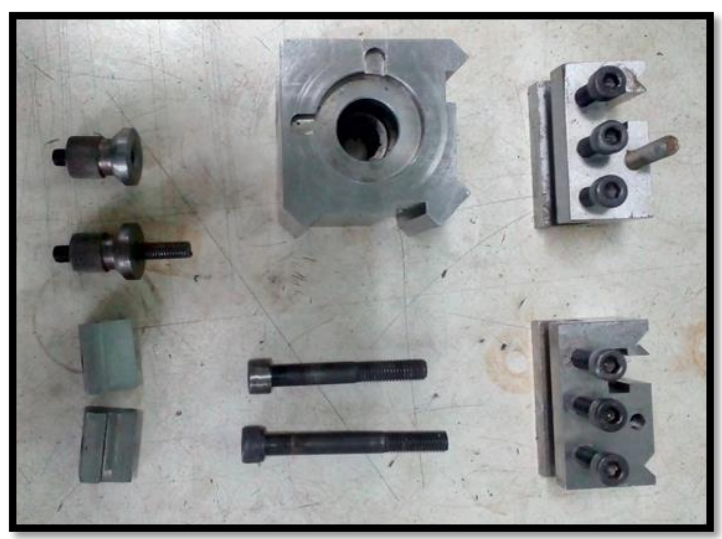

Gambar 6. Komponen Hasil Proses Produksi

Tahap ketiga adalah melakukan evaluasi produk hasil produksi dengan dua jenis uji coba yaitu uji kelayakan dan uji coba yang diperluas. Produk awal hasil proses produksi dilakukan uji kelayakan atau uji coba terbatas yang dilakukan bersama antara teknisi, peneliti dan dosen pengampu praktik pemesinan bubut di Workshop Fitting Jurusan Pendidikan Teknik Mesin FT UNY. Tujuan uji coba ini adalah untuk memastikan bahwa produk Quick Change Toolpost Sets and Holders baik secara fungsional maupun operasional dapat digunakan untuk proses pembubutan. Berikut ini adalah data teknis proses uji coba yang dilakukan: (1) Mesin bubut Ciamix seri SP $6230 \mathrm{~T}$, (2) Pahat bubut rata ukuran $5 / 8$ inchi, (3) Material/bahan yang dibubut adalah Mild Steel dengan $\varnothing 25,4 \mathrm{~mm}$, (4) Parameter pembubutan: putaran spindel 600-1000 rpm, feeding $0,05 \mathrm{~mm}$ dan depth of cut: $0,25,0,50$, dan $0,75 \mathrm{~mm}$. Pelaksanaan uji kelayakan atau uji coba terbatas dilakukan dengan beberapa kali proses pembubutan dengan variasi putaran spindel dan juga variasi ketebalan pemakanan.

Hasil uji kelayakan atau uji coba terbatas menunjukkan bahwa: (1) Produk Quick Change Toolpost Sets and Holders dapat digunakan secara fungsional dan operasional secara baik, (2) Proses pembubutan berjalan dengan baik, posisi pahat tetap stabil dan tidak terpengaruh getaran akibat putaran mesin, (3) Variasi tebal pemakanan sampai dengan 0,75 $\mathrm{mm}$, namun kondisi toolpost masih normal dan proses pembubutan masih berjalan dengan baik. Hal ini menunjukkan bahwa dari segi kekuatan toolpost memiliki kategori baik, (4) Hasil pembubutan dengan beberapa variasi putaran maupun tebal pemakanan menunjukkan hasil yang baik.

Namun demikian masih terdapat beberapa catatan yang harus diperbaiki yang ditemukan selama proses uji kelayakan tersebut, yaitu: (1) Panjang holder 1 (perhatikan Gambar 7) masih kurang panjang. Hal ini menyebabkan posisi pemasangan pahat masih terlalu panjang pada bagian di luar holder, sehingga dikhawatirkan pahat akan mudah patah dan dinilai kurang aman dari sisi keselamatan kerja, (2) Panjang baut pengikat pahat pada holder (komponen no 4) masih terlalu panjang. Kondisi ini secara prinsip sebenarnya tidak mempengaruhi fungsional alat maupun aspek keselamatan kerja, namun secara estetika kurang enak dilihat, (3) Ukuran kepala baut yang berbeda-beda pada komponen no 1, 4 dan 8. Hal ini memerlukan tiga jenis ukuran kunci $L$ yang digunakan selama proses pekerjaan, 
sehingga secara operasional dinilai kurang efisien.

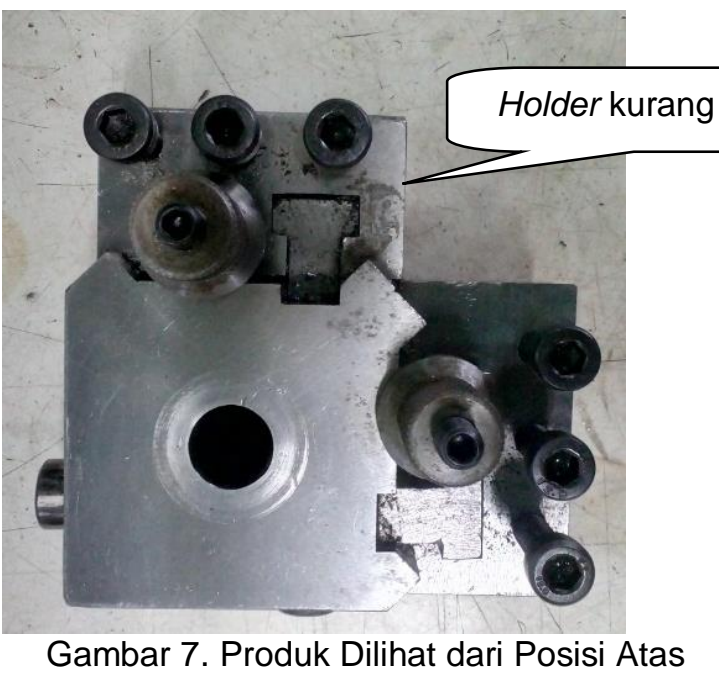

Proses uji coba selanjutnya adalah penggunaan produk oleh mahasiswa dalam proses pembelajaran praktik (Gambar 8) untuk mengetahui respon dan memperoleh masukan terkait dengan
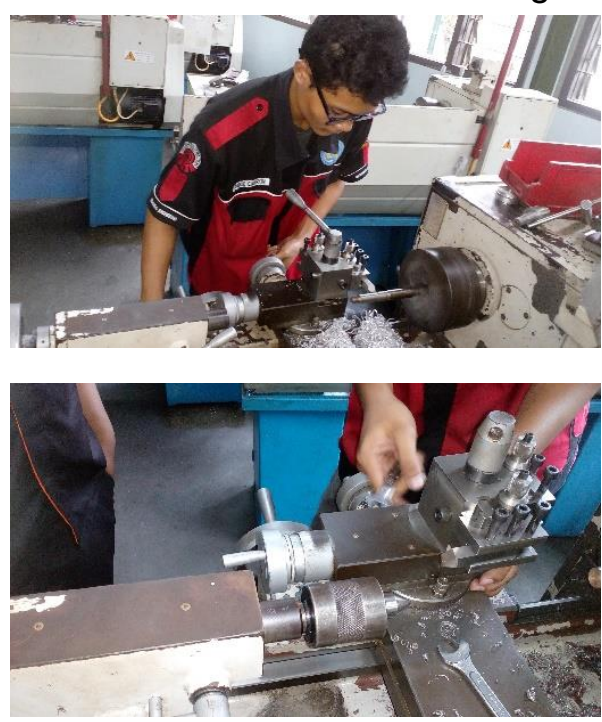

fungsional dan operasional produk Quick Change Toolpost Sets and Holders. Proses uji coba diawali dengan penjelasan oleh tim peneliti kepada mahasiswa yang Jan menggunakan produk tersebut kait dengan cara pemasangan toolpost pada eretan atas, pemasangan pahat pada holder, langkah penyetelan pahat supaya setinggi center benda kerja, parameter pembubutan yang digunakan dan aspek keselamatan kerja. Berikut ini adalah data teknis proses uji coba yang dilakukan oleh mahasiswa: (1) Mesin bubut Ciamix seri SP $6230 \mathrm{~T}$ beserta kelengkapannya, (2) Pahat bubut rata ukuran $1 / 2$ dan 5/8 inchi, (3) Material/bahan yang dibubut adalah Mild Steel atau alumunium dengan ukuran menyesuaikan joobsheet yang sedang dikerjakan, (4) Parameter pembubutan: putaran spindel antara $600 \mathrm{rpm}$ sampai $1000 \mathrm{rpm}$, feeding $0,05 \mathrm{~mm}$ dan depth of cut: $0,25,0,50$, dan $0,75 \mathrm{~mm}$.
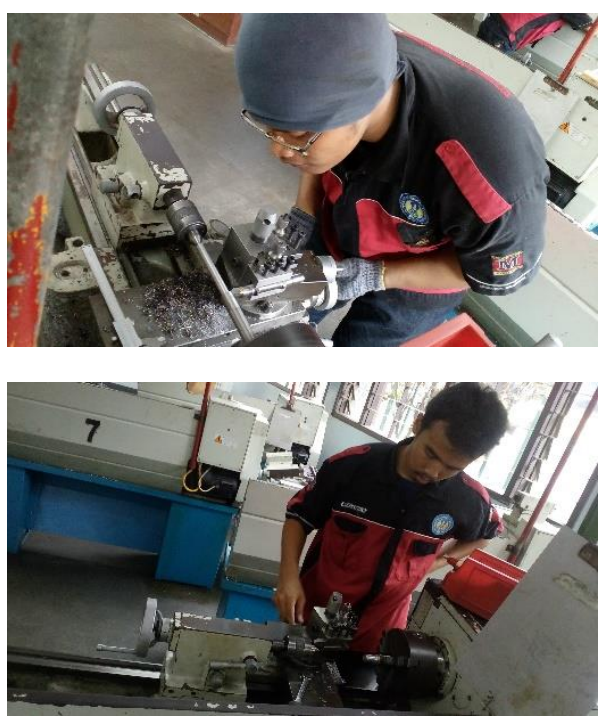

Gambar 8 Uji Coba Produk oleh Mahasiswa

Instrumen yang digunakan untuk pengamatan dalam uji coba oleh mahasiswa ini terdiri dari 3 bagian yaitu: data parameter pembubutan yang digunakan, data penilaian kuantitatif dan penilaian kualitatif berupa saran atau masukan dari mahasiswa.. Data penilaian produk secara kuantitatif oleh mahasiswa yang merupakan hasil uji coba ditunjukkan pada Tabel 2.

Hasil penilaian oleh mahasiswa sebagaimana disampaikan dalam Tabel 5 di atas menunjukkan bahwa produk memiliki kelayakan dengan skor sebesar 3,64 yang berarti "BAIK", sehingga dapat digunakan dengan baik secara fungsional maupun operasional, mampu menahan getaran saat proses pembubutan, dan 
hasil pembubutan dengan beberapa variasi putaran maupun tebal pemakanan menunjukkan hasil yang baik. Berdasarkan hasil tersebut dapat disimpulkan bahwa produk yang dikembangkan layak untuk digunakan dalam pembelajaran.

Hasil uji coba mahasiswa selain data kuantitatif yang disajikan di atas juga diperoleh oleh data kualitatif berupa saran atau komentar mahasiswa yang secara ringkas disajikan sebagai berikut: (1) Memudahkan operator mesin bubut dalam menyetel tinggi pahat, (2) Tidak perlu menggunakan plat pengganjal dan cukup memutar baut pengaturnya saja untuk memperoleh pahat bubut setinggi center. (3) Lebih hemat waktu kerja dalam mengatur tinggi pahat. (4) Jumlah alat (produk ini) diperbanyak lagi. (5) Pemasangan pahat pada 2 holder dapat lebih mempercepat proses apabila ada 2 jenis pekerjaan (bubut rata dan ulir). (6) Posisi dudukan (holder) perlu diperbaiki agar dapat digunakan pahat ukuran panjang (pahat insert dengan holder yang panjang)

Tabel 2. Penilaian Produk oleh Mahasiswa

\begin{tabular}{llcc}
\hline No. & \multicolumn{1}{c}{ Aspek yang Diamati } & $\begin{array}{c}\text { Rerata } \\
\text { (skala 5) }\end{array}$ & Inter-pretasi \\
\hline 1 & $\begin{array}{l}\text { Petunjuk penggunaan quickchange toolpost sets and holders } \\
\text { mudah dipahami }\end{array}$ & 3,83 & Setuju \\
2 & $\begin{array}{l}\text { Pengoperasian quickchange toolpost sets and holders } \\
\text { mudah }\end{array}$ & 4,17 & Setuju \\
3 & $\begin{array}{l}\text { Quickchange toolpost sets and holders dapat berfungsi } \\
\text { dengan baik }\end{array}$ & 3,50 & Setuju \\
4 & $\begin{array}{l}\text { Quickchange toolpost sets and holders mampu menahan } \\
\text { getaran selama proses pembubutan }\end{array}$ & 3,33 & Cukup Setuju \\
6 & $\begin{array}{l}\text { Quickchange toolpost sets and holders memiliki kekuatan } \\
\text { yang baik }\end{array}$ & 3,50 & Setuju \\
7 & $\begin{array}{l}\text { Hasil pembubutan menggunakan quickchange toolpost sets } \\
\text { and holders baik }\end{array}$ & 3,50 & Setuju \\
& $\begin{array}{l}\text { Secara umum, produk quickchange toolpost sets and holders } \\
\text { sudaik }\end{array}$ & 3,67 & Setuju \\
\hline
\end{tabular}

Tahap keempat adalah melakukan diseminasi produk, yaitu menyampaikan produk hasil penelitian dan pengembangan yang berupa Quick Change Toolpost Sets and Holder kepada para pengguna dan profesional melalui forum seminar hasil penelitian yang diselenggarakan oleh Jurusan Pendidikan Teknik Mesin FT UNY. Selain itu juga menuliskan dalam jurnal ilmiah nasional JPTK yang diterbitkan oleh Fakultas Teknik Undhiksa.

\section{Spesisifikasi dan Keunggulan Produk}

Produk ini juga didesain memiliki 2 holders yang terpasang pada toolpost, sehingga dapat dipasang 2 jenis pahat yang dapat digunakan untuk beberapa jenis pekerjaan tanpa harus bongkar pasang pahat terlebih dahulu, cukup dengan memutar posisi toolpost saja. Produk ini juga didesain agar user friendly (mudah digunakan oleh operator) yaitu pengaturan tinggi holder pahat dilakukan hanya dengan memutar baut pengatur sehingga ujung mata sayat pahat akan dengan mudah diatur setinggi senter mesin bubut. Desain produk ini sudah terwujud dalam suatu produk dan terbukti dapat memenuhi sesuai harapan pengguna. Pengembangan quick change tool post ini dimaksudkan untuk lebih mengoptimalkan pemanfaatan mesin bubut saat digunakan untuk proses produksi. Model modifikasi kemampuan mesin bubut ini juga seperti yang dilakukan oleh Muhammad Yanis (2010) dalam penelitiannya modifikasi mesin bubut dengan penambahan alat bantu cekam untuk membuat komponen yang 
membutuhkan proses frais. Perlatan bantu yang dibuat tersebut memungkinkan mesin bubut dapat digunakan untuk fungsi proses pengefraisan muka.

Proses pembuatan produk dalam rangka mewujudkan desain juga tidak mengalami kesulitan. Konsep desain produk dibuat sederhana namun memenuhi kebutuhan secara fungsional dan operasional, sehingga mempermudah proses machining-nya. Pembahasan di atas menunjukkan bahwa produk yang dikembangkan memiliki keunggulan dan kelebihan yaitu: (1) desain yang sederhana namun sudah mampu memenuhi kebutuhan pengguna untuk mengatur pahat setinggi center mesin dengan mudah serta lebih hemat waktu, (2) pengoperasian dalam penggunaan produk yang mudah dan sederhana, dan (3) proses machining yang mudah dan peralatan yang diperlukan sederhana.

\section{Kelayakan Produk}

Stella Daran Hindom (2015) menyatakan bahwa parameter pemesinan yang paling berpengaruh terhadap gaya pemotongan adalah putaran. Hasil uji kelayakan yang dilakukan bersama antara teknisi, peneliti dan dosen pengampu praktik pemesinan bubut menunjukkan hasil yang memuaskan. Produk Quick Change Toolpost Sets and Holder dapat berfungsi dengan baik dan mampu untuk melaksanakan pembubutan dengan berbagai variasi putaran mesin dan juga variasi ketebalan pemakanan. Pahat tetap dalam kondisi stabil selama proses pembubutan, dimana hal ini menunjukkan bahwa produk ini mampu menahan getaran yang ditimbulkan oleh mesin bubut. Saran dan masukan yang diperoleh pada uji kelayakan ini juga lebih pada hal yang sifatnya pelengkap (panjang baut, variasi ukuran kuci $L$ dan panjang holder) sehingga secara prinsip paroduk ini sudah dapat dikatakan layak untuk digunakan mendukung proses pembubutan.

Hasil uji coba yang dilakukan oleh mahasiswa yang melaksanakan praktik pembubutan juga menunjukkan hasil yang memuaskan juga, yaitu memperoleh skor rata-rata sebesar 3,64 (pada skala 5). Skor tersebut apabila dikonversikan ke interval penilaian maka masuk pada kategori "BAIK". Hal ini menunjukkan bahwa produk ini sudah memenuhi harapan atau kebutuhan pengguna, sehingga dapat dikatakan bahwa produk ini layak untuk dioperasikan. Hasil kuantitatif tersebut juga didukung dengan saran dan komentar dari mahasiswa pengguna yang pada umumnya menyatakan bahwa produk ini sangat membantu memudahkan operator mesin bubut dalam menyetel tinggi pahat, dimana operator tidak perlu menggunakan plat pengganjal pahat dan cukup memutar baut pengaturnya saja untuk memperoleh pahat bubut setinggi center. Mahasiswa yang lainnya juga mengatakan bahwa produk ini dapat membantu menjadi lebih hemat waktu kerja untuk persiapan proses pembubutan dalam mengatur tinggi pahat.

\section{Kemampuan Produk dalam Mendukung Praktik Pemesinan Bubut}

Hasil uji kelayakan maupun uji coba yang sudah dilakukan menunjukkan bahwa produk Quick Change Toolpost Sets and Holder mampu dioperasikan dengan baik sehingga dapat digunakan untuk mendukung kelancaraan proses pembelajaran praktik di bengkel. Kemampuan produk secara fungsional maupun operasional sudah terbukti melalui uji kelayakan dan uji coba yang dilakukan. Hal ini menunjukkan bahwa dari sisi ukuran dan geometri produk sudah memenuhi sesuai analisis kebutuhan yang ada.

Analisis kebutuhan yang diidentifikasi sebelumnya mampu dipenuhi oleh produk yang dibuat, yaitu: (1) dapat dipasang di mesin bubut yang tersedia di bengkel (Ciamix seri SP $6230 \mathrm{~T}$ ) dan cara pemasangan praktis pada dudukan eretan atas, (2) mudah dioperasikan oleh mahasiswa baik yang sudah berpengalaman dalam menggunakan mesin bubut atau yang belum, (3) dapat digunakan untuk beberapa variasi ukuran pahat bubut yang sering digunakan untuk proses praktik, (4) dapat diatur ketinggian 
sisi sayat pahat dengan mudah ketika diperlukan pergantian jenis pahat yang digunakan dalam proses pemesinan, (5) pahat tetap stabil dan tahan terhadap getaran yang ditimbulkan karena penggunaan putaran yang tinggi saat proses pembubutan, dan (7) tidak perlu lagi menggunakan pengganjal pahat. Semua kebutuhan yang diindetifikasi tersebut berdasarkan hasil uji coba yang dilaksanakan mahasiswa dapat dipenuhi oleh produk Quick Change Toolpost Sets and Holder.

\section{Keterbatasan yang Masih Ditemukan}

Beberapa kelemahan yang masih ditemukan pada produk Quick Change Toolpost Sets and Holder hasil pengembangan ini, yaitu: (1) Variasi ukuran kunci $L$ yang digunakan masih banyak yaitu ukuran M6, M8, dan M10 sebaiknya baut pengikat yang digunakan dibuat seragam satu ukuran sehinggga cukup menggunakan 1 jenis kunci $L$ saat pengoperasiannya. (2) Produk ini masih terbatas untuk mendukung proses pengerjaan bubut luar dan belum dapat digunakan untuk proses pengerjaan bubut dalam maupun ulir dalam. (3) Ukuran lubang utama masih hanya sesuai untuk mesin bubut jenis Ciamix seri SP $6230 \mathrm{~T}$, perlu dibuatkan desain agar produk ini dapat digunakan pada berbagai jenis mesin bubut dengan berbagai ukuran.

\section{SIMPULAN DAN SARAN}

Berdasarkan hasil pemaparan data dan pembahasan di atas, maka dapat disimpulkan bahwa produk hasil pengembangan ini adalah berupa Quick Change Tool post Sets and Holders: (1) Memiliki spesifikasi dan keunggulan sebagai berikut: dapat digunakan pada mesin bubut Ciamix seri SP $6230 \mathrm{~T}$, memiliki 2 holders pahat yang terpasang pada tool post, dan pengaturan tinggi holder pahat cukup dilakukan hanya dengan memutar baut pengatur sehingga ujung mata sayat pahat akan dengan mudah diatur setinggi senter mesin bubut. Produk ini memudahkan operator mesin bubut dalam menyetel tinggi pahat, tidak perlu menggunakan plat pengganjal dan lebih hemat waktu kerja dalam mengatur tinggi pahat. (2) Memiliki kelayakan dengan skor sebesar 3,64 dengan kategori "BAIK". Produk ini dapat digunakan dengan baik secara fungsional maupun operasional, posisi pahat tetap stabil dan tidak terpengaruh getaran akibat putaran mesin pada proses pembubutan, mampu digunakan sampai dengan ketebalan pemakanan sebesar 0,75 mm, dan hasil pembubutan dengan beberapa variasi putaran maupun tebal pemakanan menunjukkan hasil yang baik.

Saran untuk penelitian selanjutnya agar: (1) dilakukan pengembangan untuk memodifikasi produk Quick Change Tool post Sets and Holder tersebut untuk mengatasi kelemahan yang masih ada (2) perlu dilakukan penelitian lanjutan untuk mengukur tingkat efektivitas pembelajaran praktik yang menggunakan produk Quick Change Toolpost Sets and Holders ini di Workshop Fitting Jurusan Pendidikan Teknik Mesin Fakultas Teknik UNY.

\section{DAFTAR PUSTAKA}

Aep Surahto. (2008). Modifikasi Mesin Bubut Sebagai Mesin Penguji In Line Type Injection Pump. Jurnal Paradigma Vol 9, No 01.

Budiman, A., dan Priambodo, B. (1999). Elemen Mesin Jilid 1 (G. Niemann. Terjemahan). Jakarta : Erlangga.

Gall, M.D., Gall, J.P., dan Borg, W.R. (2003). Educational Research: An Introduction ( $7^{\text {th }}$ Edition). New York: Allyn \& Bacon.

Ignatius Aris Hendaryanto, dan Andhi Akhmad Ismail. (2014). Retrofit Mesin Bubut di Laboratorium Teknologi Mekanik Diploma Teknik Mesin Sekolah Vokasi Universitas Gadjah Mada. Laporan Penelitian, tidak diterbitkan, Universitas Gadjah Mada.

Muhammad Yanis dan Qmarul Hadi. (2010). Modifikasi Mesin Bubut dengan Penambahan Alat Bantu Cekam untuk Membuat Komponen yang Membutuhkan Proses Freis. 
Prosiding Seminar Nasional Tahunan Teknik Mesin (SNTTM) ke9. Hal MV111-MV116.

Nana Syaodih Sukmadinata. (2009). Metode Penelitian Pendidikan. Bandung: PT. Remaja Rosdakarya.

Nurdjito. (2015). Rencana Pembelajaran Semester Pemesinan Bubut. Yogyakarta: Jurusan Pendidikan Teknik Mesin FT UNY.

Punaji Setyosari. (2010). Metode Penelitian Pendidikan dan Pengembangan. Jakarta: Kencana.

Stella Daran Hindom, Rudy Poeng, dan Romels Lumintang. (2015). Pengaruh Variasi Parameter Proses Pemesinan Terhadap Gaya Potong pada Mesin Bubut Knuth DM-1000A. Jurnal Online Poros Teknik Mesin Volume 4 Nomor 1. Hal 36-48.
Sugiyono. (2015). Metode Penelitian dan Pengembangan. Bandung. Alfabeta

Tim Kurikulum. (2014). Pedoman kurikulum Jurusan Pendidikan Teknik Mesin Fakultas Teknik UNY.

Trianto. (2009). Mendesain model pembelajaran inovativ-progresif. Jakarta.Kencana Prenada Media Group.

Widarto. (2008). Teknik Pemesinan untuk SMK. Jakarta. Direktorat Pembinaan Sekolah Menengah KejuruanDepartemen Pendidikan Nasional

Winataputra, U. S., et al. (2008). Teori belajar dan pembelajaran. Jakarta.Penerbit Universitas Terbuka. 